\title{
Analysis of The National Character Senior High School Students by Using Rasch Model
}

\author{
Wahyu Hidayat ${ }^{1}$, Sri Mulianah $^{2}$, Mujahidah $^{3}$ \\ \{wahyuhidayat@iainpare.ac.id ${ }^{1}$, srimulianah $^{2}$, mujahidah@iainpare.ac.id ${ }^{3}$ \}
}

IAIN Parepare, Amal Bakti Street No.8 Parepare 91131, South Sulawesi Indonesia ${ }^{1,2,3}$

\begin{abstract}
The Indonesian educational ministry has moved to emphasize the national character education as an integrated element in the 2013 curriculum. Character is nurtured through a continuous process with character education. The result of which, is the development of students' characters, which fits the general community's aspirations. The study objectifies to describe the national characters of students of upper middle school in southern Sulawesi Province, using the national character inventory (IKB). The analysis of data for the study is of quantitative manner, and is be done using the Rasch model of measurement. The result of the study points to the students' characters leans towards religiosity and appreciating performance and skews away from creativity.
\end{abstract}

Keywords: Character Achievement of Students and The National Character Inventory.

\section{Introduction}

Character is exclusive to humans. Lickona defined character as conscience, emotion, and action [1]. Character is developed from a value system that is formed by the individual [2]. Value functions as Confidence, standard, guide and motif that develops character [3], [4]. The process to develop and mold a person's character is called character education [5], [6].

A study done by Kibler et al[7], pointed to the lack of character strength as a reason for juvenile delinquencies to happen. Furthermore, Josephnson [8]mentioned that $82 \%$ of students admitted that they have lied to their parents and $60 \%$ of the students have lied in tests. Consequently, Hart and Carlo [9]contended $75 \%$ of juvenile delinquencies is caused by a weak character.

Competency and character is a symbiotic union that is dependent on each other [10], [11]. A student having the characteristic qualities of: honesty, hardwork, religious, appreciative of learning opportunities and discipline, has a better chance of achieving high academic performance than a student having little or absent of such qualities [12], [13]. A study by Berkowitz and Hoppe[14] found out that students with high self-esteem are better facing stress and making independent decisions than students who has low self-esteem. In lieu of this, Indonesia is placed in 115 out of 139 countries on the Global Creativity Index (GCI) for 2015 [28]. This survey is done by the Martin Prosperity Institute, in evaluating the creativity index of a country [28]. Thus, this points to a lack of creativity, which may have its roots in the strength of character of Indonesian youth

Character Education is an integral component for the development of a nation and its people. The loss or weakening of the character of a community will lead to the loss of the character that defines a group of people. Character plays an important role in driving and 
determining the strength of a group of people and holding it steadfast. Character must be nurtured and developed to produce a strong and dignified people as it is not something that develops on its own [15]. Character development in Indonesia must be focused on three factors which are: nurturing and strengthening national identity, strengthening Indonesia as a unified country, and Indonesians having positive virtues and a dignified people [16].

Individual character is not hereditary, in fact, it is developed continuously through thoughts and actions on a daily basis, which consequently means that, character development is a continuous and conscious effort. students' character is an outcome of a learning experience [17]. This entails that character is a product of an educational process, and thus needs to measured [18]. Hence, the development of a measuring mechanism that is valid and reliable is imperative.

One of the major theoretical approach used in character measurement is the theory of character precedence and strength. The theory has 6-character precedence values and 24 character strength values. Wahyu Hidayat[19] in his study, merged a few theories and developed a national character inventory or Inventori karakter bangsa (IKB). The inventory unifies the theory of character precedence and strength and essential values from religions and the 'Pancasila' (the core values of the Indonesian nation). The IKB has 18 -character values which are: religiosity, honesty, tolerance, discipline, hard work, creative, independent, democratic, inquisitive, national pride, love of country, appreciation of performance, friendship or communicative, love, peace, love of reading, love of environment, socially conscious, and responsibility.

Inventory is one of the instruments that has been used repeatedly in identifying and measuring the structure of character, personality, thought process, emotion, and actions [20]. Hence, the character inventory used, can illustrate the traits of individuals on their characters, with the objective of individuals having a deeper understanding of themselves, from an objective point of view.

\section{Research method}

\subsection{Participants}

The study was administered on 550 samples. The sample can be broken down to 300 females (54.55\%) and 250 males (45.45\%). The religion break down is 300 Muslims (54.55\%) and 250 Christians (45.45\%). The ethnics involved are Bugis $300(54.55 \%)$ and $250(45.45 \%)$ Tanah Toraja (Tator). The type of schools involved are 300 students $(54.55 \%)$ from the middle schools and 250 students $(45.45 \%)$ are from technical middle Schools.

\subsection{Measures}

The inventory used (IKB) consist of 81 items and 18-character values, with alpha Cronbach value of (KR-20) 0.78 .

\subsection{Statistical analysis}

The study applied the Rasch Model Analysis as its statistical tool. The Rasch Model Analysis is a measurement model the evaluates the values of items in the instrument developed based on certain criteria. The models can change raw data to interval data of the equal values 
between unit to another [21]. The model can calculate how the items and respondents interact, that is illustrated concurrently, in an analysis that shows the ability of the students and the difficulty of item, using the same linear scale [22], [23].

\section{Results}

The item measure for IKB is represented in Table 1.

Table 1. Item measure for IKB.

\begin{tabular}{|c|c|c|}
\hline No & Logits & Items \\
\hline 1 & 1.23 & Having a lot of ideas \\
\hline 2 & 1.16 & Inclination Towards creating something that is new and different \\
\hline 3 & 1.16 & Having the initiative to answer teachers' questions \\
\hline 4 & 1.12 & Inclination Towards creating something that is new \\
\hline 5 & 1.09 & Giving Ideas when asked for \\
\hline 6 & 0.89 & Having ideas that are creative and innovative \\
\hline 7 & 0.44 & Congratulate friends \\
\hline 8 & 0.27 & Avoidance of slander in all matters \\
\hline 9 & 0.27 & Visits sick friend \\
\hline 10 & 0.22 & Avoidance of hoaxing in taking exam matters \\
\hline 11 & 0.22 & A person of his/her words \\
\hline 12 & 0.15 & Fully focused when learning \\
\hline 13 & 0.14 & Utter Salam to friends in and out of schools \\
\hline 14 & 0.13 & Equal treatment to all regardless of who they are \\
\hline 15 & 0.13 & Provides Equal workload to al team members \\
\hline 16 & 0.12 & Does not mind with littered garbage although he/she is able to clean it \\
\hline 17 & 0.12 & Prioritize the Indonesian language within the school compound \\
\hline 18 & 0.09 & Maintaining teamwork with all team members when doing the assigned task \\
\hline 19 & 0.06 & Nonchalance attitude when seeing people vandalizing public park \\
\hline 20 & 0.06 & A strong belief in self \\
\hline 21 & 0.05 & Prioritize local products than imports \\
\hline 22 & 0.05 & Pride of being born in Indonesia \\
\hline 23 & 0.05 & Giving critique to friends \\
\hline 24 & 0.04 & Routinely reads the holy scripture \\
\hline 25 & 0.04 & Hard to give help to others \\
\hline 26 & 0.03 & Always returns borrowed goods \\
\hline 27 & 0.03 & Does not give up in understanding hard subjects when learning \\
\hline 28 & 0.01 & A tendency to defend the diverse language, culture, and etnics of Indonesia \\
\hline 29 & 0.01 & Rarely gives donations although more than capable \\
\hline 30 & 0.00 & Reliable in entrusting care of friends' goods \\
\hline 31 & 0.00 & Willing to sacrifice for the Good of Indonesians \\
\hline 32 & -0.01 & Let the needs of the many outweighs the needs of self \\
\hline 33 & -0.01 & Always strife to find extra information on subjects learned \\
\hline 34 & -0.03 & involved in maintaining the unity of Indonesians \\
\hline 35 & -0.03 & Easy to give when faced with obstacles in learning \\
\hline 36 & -0.03 & Always seek apology when commit something wrong \\
\hline 37 & -0.04 & Respects other religion prayers and practices \\
\hline 38 & -0.04 & Learned the history of the region \\
\hline 39 & -0.05 & Having interest in new elements in academia \\
\hline 40 & -0.06 & Likes to fool around than read \\
\hline
\end{tabular}




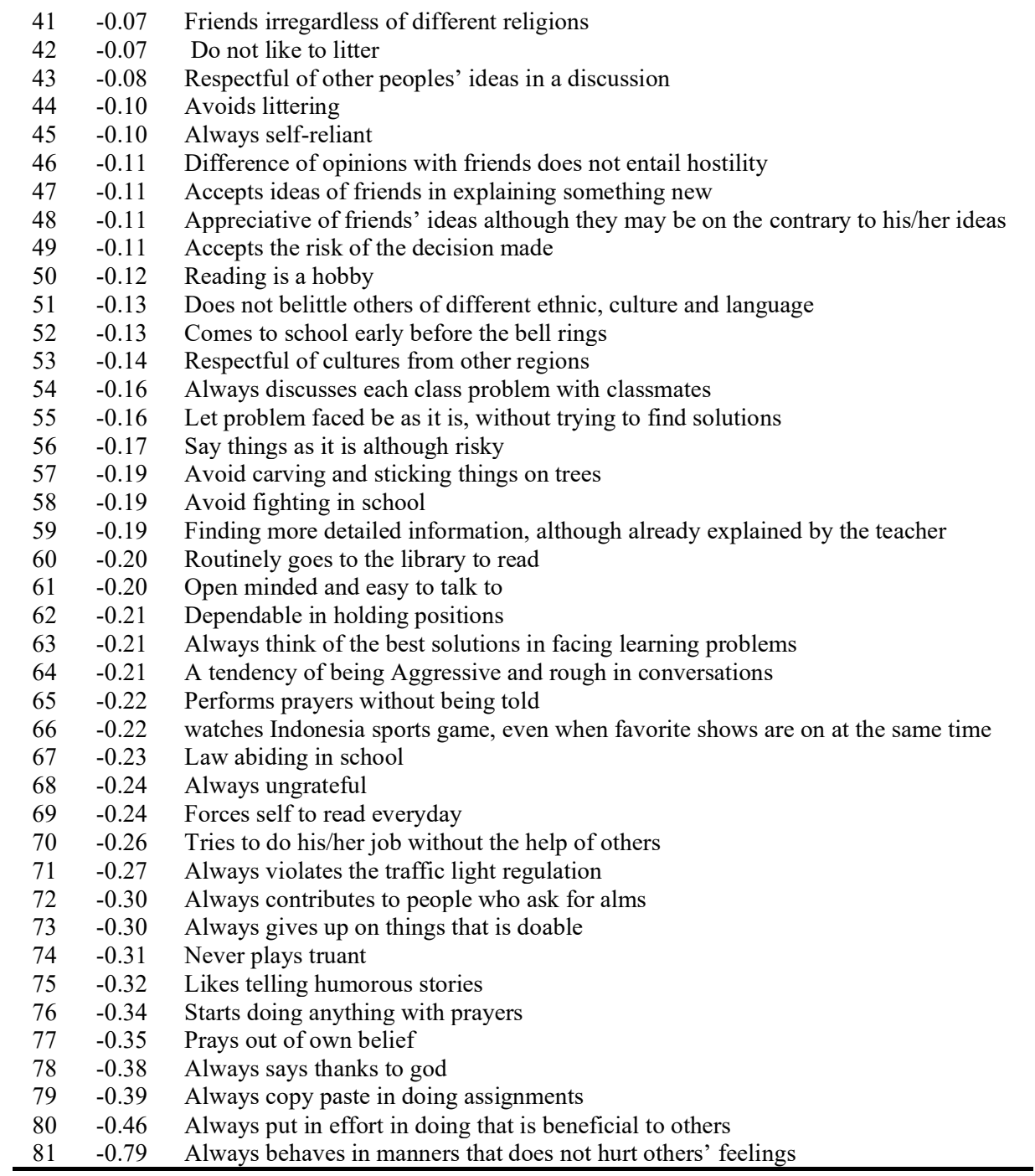

Based on Table 1, the highest logits values show strong disagreement, while the lowest logits values point to strong agreement.The result of the analysis showed that the lowest agreement for charater traits of the students is "Having lots of ideas" (1.23 logit). Meanwhile the character trait that shows strong agreement by the students is "Always behaves in manners that does not hurt others' feelings".

The other five characters that the students showed strong disagreement in having are: "Having a lot of ideas" (1,23 logit), "Inclination Towards creating something that is new and different" (1.16 logit), "Having the initiative to answer teachers' questions" (1.16 logit), "Inclination Towards creating something that is new" (1.12 logit), and "Giving Ideas when asked for" (1.09 logit). Meanwhile, the five character traits that the students showed strong 
agreement to is : "Prays out of own belief" (-0.35 logit), "Always says thanks to god" (-0.38 logit), "Always copy paste in doing assignments" (-0.39 logit), "Always put in effort in doing that is beneficial to others" (-0.46 logit), and "Always behaves in manners that does not hurt others' feelings" (-0.79 logit). The average of the character traits values is shown in Table 2

Table 2. Average of item measure values for national characters.

\begin{tabular}{clc}
\hline No & \multicolumn{1}{c}{ Constructs } & Difficulty average (Logit) \\
\hline 1 & Religosity & -0.25 \\
2 & Honesty & +0.05 \\
3 & Tolerance & -0.08 \\
4 & Observance of Nature & -0.01 \\
5 & Discipline & -0.23 \\
6 & Democratic & +0.005 \\
7 & Love of Nation & +0.005 \\
8 & Patriotism & -0.008 \\
9 & Creativity & +1.108 \\
10 & Inquistive & -0.09 \\
11 & Love of Reading & -0.155 \\
12 & Hardwork & -0.09 \\
13 & Self Reliant & -0.010 \\
14 & Socially Aware & +0.07 \\
15 & Love of Peace & -0.127 \\
16 & Friendship & -0.143 \\
17 & Appreciation of Performance & -0.267 \\
18 & Responsibility & 0.003 \\
\hline
\end{tabular}

Result of the analysis showed that the students have the qualities of: Creativity $(+1.18$ logit), Honesty (+0.05 logit), and Socially Aware (+0.07 logit) the least. The national character the students showed strong agreement to are: Religiosity (-0.248), Appreciation of Performance (0.267 logit), Discipline (-0.226), Friendship (-0.143 logit), Love of Peace (-0.127 logit), Love of reading (-0.155 logit), and Inquisitive (-0.09 logit).

\section{Item and respondent reliability in IKB}

The acepted item reliability index for this study is over 0.70 as it is considered a sufficient value [24], [25].Table 3 details the item reliabilty in the study:

Table 3. Item dan person reliability.

\begin{tabular}{cccc}
\hline & Reliability & Person & $\begin{array}{c}\text { Cronbach Alpha } \\
\text { (KR-20) }\end{array}$ \\
\hline Real RMSE & 0.97 & 0.79 & \\
Model RMSE & 0.97 & 0.80 & 0.80 \\
Separation & 3.33 & 2.74 & \\
\hline
\end{tabular}

The result of the item reliability analysis showed that reliability level is at 0.97 which is very high and nearing the maximum value of $1[26]$. The persons' reliability is at 0.80 , which is 
at a good level. Furthermore, the Cronbach Alpha (KR-20) is at 0.80 . this value points a respondent consistency in using different items but testing the same construct [27]. The number of samples involved in the study is also shown to be sufficient by these results, in developing the instrument to gauge the Indonesian national character.

The item separation index of the study is at 3.33, which leads to the items being divided to three different levels of: high, medium, and low. A separation index that is above two is accepted as valid. Figure 1 shows students' character tendency according to the 18 characters proposed

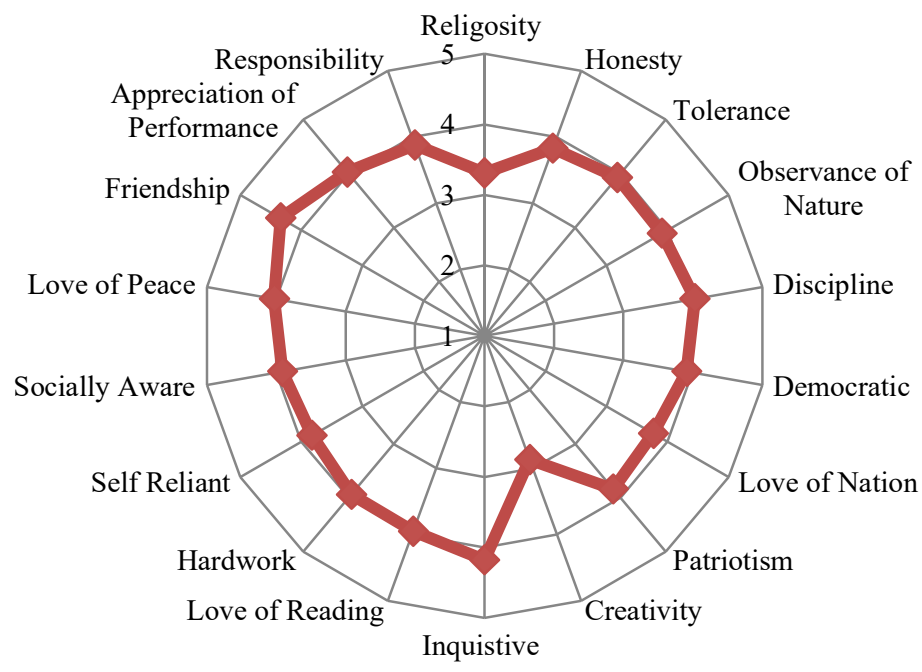

Fig. 1. Character tendency of the national characters of students.

Female students exhibit a higher tendency towards religious, honesty, inquisitive, and responsibility characters than male students. The male students meanwhile, showed a tendency to characters such as friendship, tolerance, hard work, and patriotism

Figure 2 illustrates the tendencies of the 18 characters of Senior High School students according to their religious backgrounds of Islam and Christianity. 


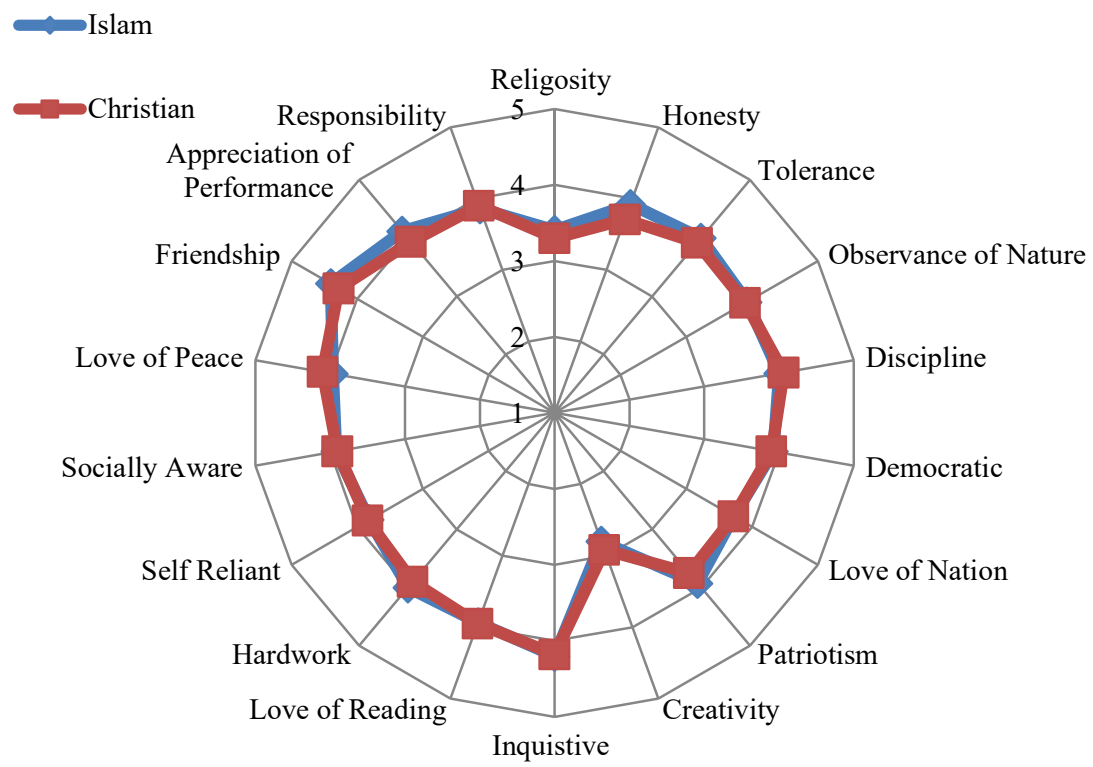

Fig. 2. Character tendencies according to religious backgrounds.

Figure 2 illustrates all the characters have the same tendencies irrespective of their religious backgrounds. There are minimal differences to the religious and honesty characteristics, with relative differences.

\section{Discussion}

The result of the study points to the fact that the character which the students have weak affiliation to is "having a lot of ideas", which supports a few researches done that contended to the low level of creativity among Indonesian students [28]. Contrastingly, this research also contradicts findings of Linley and Harrington [29], which states that men have stronger tendency to creativity than woman.

A study by Shimai et al. [30] mentioned that there are character differences because of tendencies towards religion. Similarly, this study found that female students have stronger tendencies than men for characters: Religious, Honesty, Discipline, being inquisitive, and responsibility. One of the hallmarks of the religious character is being thankful, and in Linley \& Harrington [29] study, it is concluded that women have stronger tendency than men to feel thankful, similar to this study. This study also concluded that men and women have equal level of tendency in being socially conscious. This is different from findings of Linley \& Harrington [29], which states that women have stronger tendency than men in being socially conscious. Men on the other hand have strong tendency to be creative [30]. It is largely believed that the 
strength of character is largely influenced by the spiritual and religious strength of a respondent [30].

\section{References}

[1] Lickona, T. What is Good Character? And How can We Develop it in Our Children. Reclaiming Children and Youth 9 (4), pp. 239-251 (2001).

[2] Peterson, C. dan Seligman, M. E. P. Character Strengths and Virtues: A Handbook and Classification. Oxford University Press (2004).

[3] Allport, Gordon W. Personality: A Psychological Interpretation. New York: Henry Holt and Company, (1961).

[4] Lickona, Thomas. Educating for character: How Our Schools Can Teach Respect and Responsibility. New York: Bantam Books (2013).

[5] Samani, Muchlas \& Hariyanto. Konsep dan Model Pendidikan Karakter. Bandung: PT Remaja Rosdakarya (2012).

[6] Schwartz, M. J. Introduction to character education and effective principles. In M. J. Schwartz (Ed.), Effective character education: A guidebook for future educators (pp. 1-23). New York: McGraw-Hill, (2008) .

[7] Kibler, J. L., Dollar, K. M., Sly, K., Samuels, D, Benford, M. W., Coleman, M., Lott, L., Patterson, K., \&Wiley, F. The relationship of character strengths to sexual behaviours and related risks among African American adolescents, International Journal of Behavioral Medicine. 15(4), pp. 319-327, (2008).

[8] Josephson Institute. The ethics of American youth: 2008. Los Angeles, CA: Author, (2008). Retrieved from http://charactercounts.org/programs/reportcard/2008/

[9] Hart, D., \& Carlo, G. Moral Development in Adolescence. Journal of Research on Adolescence 15(3), pp. 223-233, (2005). doi:10.1111/j.1532-7795.2005.00094.x.

[10] Osman, Abdullah., Abdullah, Muhammad Safizal \& Abdul Mana, Arman Hadi. The Effect of Character, Competency and Commitments towards Leadership Behavior of Public Institutions of Higher Learning. International Journal of Philosophy and Social-Psychological Sciences 2 (2),pp. 20-26, (2016).

[11] Bajovic, M., Rizzo, K., \& Engemann, J. Character Education Re-Conceptualized for Practical Implementation. Canadian Journal of Educational Administration and Policy. Vol. 92, pp. 1-23, (2009).

[12] Ghamrawi, Najah A. R., Ghamrawi, N., Shal, T. Perception of Character Education: The Case of Lebanese School Leaders. Open Journal of Leadership.Vol.4,pp. 129-14, (2015).

[13] Park, N. \& Peterson, C. Strengths of Character in Schools. In R. Gilman, E.S. Huebner, \& M.J. Furlong (Eds.), Handbook of positive psychology in schools. pp. 65-76. New York, NY, US: Routledge / Taylor \& Francis Group, (2009).

[14] Berkowitz, M. W. \& Hoppe, M. A. 2009. Character education and gifted children. High Ability Studies Journal 20(2),pp.131-142.

[15] Ministry of National Education. Master Book OF Character Development. Jakarta, (2010a.).

[16] The Ministry of National Education. Master Design for Character Education. Jakarta, (2010b).

[17] Cole, C. Caharacter Developments as an Outcome of the Ohio Northern University Educational Experience. Journal of College and Character 5(1), (2004).

[18] Imam Farisi, M. Development of Student Self-Assessment as a Model of Assessment and Character Development. National Scientific Conference. Assessment and Nation Character Building HEPI UNESA, pp. 68-77, (2012).

[19] Wahyu Hidayat. Developing and Validating an Inventory of a National Character (IKB) For Secondary School Students. Tesis Ph.D Universiti Kebangsaan Malaysia Bangi, (2018).

[20] Drummond, R. J., \& Jones, K. D. Assessment Procedures for Counselors and Helping Professionals. 8th Edition. Boston, MA: Pearson, (2015).

[21] Bond, T.G \& Fox, C.M. Applying the Rasch Model: Fundamental Measurement in the Human Sciences, 3th Edition New York: Routledge, (2015). 
[22] Azrilah A.A., Mohd Saidfudin M. \& Azami Z. Rasch Measurement Model Basics: Scale Formation and Measurement Structure. Bangi: Universiti Kebangsaan Malaysia., (2013).

[23] Sumintono, Bambang and Widhiarso, W. Applications of Rasch Modeling In Educational Assessment. Bandung: Trim Komunikata Publishing House, (2015).

[24] Boone, William J., Staver, John R., \& Yale, Melissa S. Rasch Analysis in the Human Sciences. London: Springer, (2014).

[25] Fisher, W.P.J. 2007. Rating Scale Instrument Quality Criteria. Rasch Measurement Transcations 21(1), 1095.

[26] Wright, B.D. \& Masters, G.N.Rating Scale Analysis.Chicago: MESA Press, (1982).

[27] Rodiah Idris.Examination of Item Functions and Generation of Generic Skills Approval Markers. $\mathrm{Ph} . \mathrm{D}$ thesis Universiti Kebangsaan Malaysia Bangi, (2010).

[28] Florida, Richard., Mellander, Charlotta \& King, Karen. The Global Creativity Index. Martin Prosperity Institute, (2015).

[29] Linley, P. A., \& Harrington, S. Playing to Your Strengths. Psychologist. Vol.19,pp. 86-89, (2006).

[30] Shimai, S., Otake, K., Park, N., Peterson, C., \& Seligman, M. E. P. Convergence of characte strengths in American and Japanese young adults. Journal of Happiness Studies. Vol7, pp. 311322, (2006). https://doi.org/10.1007/s10902-005-3647-7 